\title{
REGIONAL VARIATION OF THE SHORT-PERIOD (1 TO 10 SECOND) SOURCE SPECTRUM
}

\author{
By Yuru Zhuo* and Hiroo Kanamori
}

\begin{abstract}
We determined $\hat{m}_{b}$, the body-wave magnitude calculated from the maximum amplitude of short-period $P$ waves, of 38 large earthquakes in various tectonic provinces. The data are divided into three groups: group 1 (subduction-zone thrust events); group 2 (nonsubduction-zone dip-slip and oblique-slip events); and group 3 (strike-slip events). Groups 2 and 3 include intraplate earthquakes. Comparison of $\hat{m}_{b}$ values for these three groups of events suggests that the source spectral amplitudes of intraplate events at a period of about $1.4 \mathrm{sec}$ is 2 to 5 times larger than those of subduction-zone events with the same $M_{w}$. We also determined the source spectra of 28 large earthquakes $\left(M_{w}=6.5\right.$ to 7.7$)$ directly from Global Digital Seismographic Network (GDSN) data, over a period range from 1 to $10 \mathrm{sec}$. At periods from 1 to $2 \mathrm{sec}$, the source spectral amplitudes of intraplate earthquakes are 2 to 4 times larger than those of subduction-zone events with the same $M_{w}$. The difference decreases as the period increases to $10 \mathrm{sec}$.
\end{abstract}

\section{INTRODUCTION}

Knowledge of the earthquake source spectrum is important for understanding the mechanical conditions in the fault zone. Also, the source spectrum controls the strength of ground motions resulting from faulting. For most engineering applications, the spectral range of interest is approximately from 0.05 to $20 \mathrm{sec}$. Very shortperiod (shorter than 1 sec) spectral data can be obtained only from near-field strong ground motion data because short-period energy is strongly attenuated in the farfield. However, the distribution of strong motion instruments is so limited that very short-period data are available for only a few geographical provinces. On the other hand, seismic waves with periods longer than $1 \mathrm{sec}$ can be recorded by stations at teleseismic distances. We can therefore estimate source spectra of earthquakes in various tectonic provinces using teleseismic data at periods longer than 1 sec.

The spectral range from 1 to $10 \mathrm{sec}$ is important for safe engineering design of large structures such as high-rise buildings and oil-drilling platforms. However, the seismic source spectrum is not well known in this period range, particularly for large $(M>7)$ earthquakes. The data are especially sparse for infrequent earthquakes such as those in intraplate regions. Although they are infrequent, many of the most damaging earthquakes are intraplate events, and investigation of their source spectra is critical to seismic hazard analysis.

An important problem in this context is the estimation of strong ground motions resulting from large earthquakes in the Eastern United States. For several large earthquakes in the Western United States, high-quality strong motion records are available. These data provide a basis for estimation of strong ground motions resulting from the Western United States earthquakes (e.g., Boore, 1983). In contrast, no such data are available for the Eastern United States. In view of the high hazard potential of large earthquakes in the Eastern United States, reliable estimation of the source spectrum of earthquakes in the Eastern United States is desirable.

${ }^{*}$ On leave from the Centre for Analysis and Prediction, State Seismological Bureau, Beijing, China. 
To this end, we investigated source spectra of earthquakes in different tectonic provinces, including intraplate regions using teleseismic short-period (1 to $10 \mathrm{sec})$ records obtained from the World-Wide Standardized Seismographic Network (WWSSN) and the Global Digital Seismographic Network (GDSN).

$$
\hat{m}_{b}
$$

One of the simplest parameters to characterize high-frequency source spectrum is the 1-sec body-wave magnitude, $m_{b}$. Many investigators have compared $m_{b}$ and the surface-wave magnitude $M_{S}$ to investigate the spatial and temporal variations of seismic source spectra (e.g., Archambeau, 1978; Liu and Kanamori, 1980; Nuttli, 1983). For small events $\left(m_{b}<6\right), m_{b}$ can be used to infer the source spectrum. However, for large events $\left(m_{b}>6\right)$, a serious difficulty arises. According to the standard procedure for $m_{b}$ determination, $m_{b}$ is determined from the first few cycles of the short-period $P$ waves. However, the $P$-wave train of large events is complex, and the first few cycles of the $P$-wave train seldom represent the overall size of a large earthquake.

Furthermore, the $m_{b}$ data reported in the Earthquake Data Reports (EDR) of the U.S. Geological Survey is very heterogeneous; the way $m_{b}$ is determined differs from station to station. In order to circumvent this problem, Houston and Kanamori (1986a) introduced $\hat{m}_{b}$ which is similar to $m_{b}$ except that the maximum amplitude of the entire $P$-wave train is used for the magnitude calculation. This method follows the scheme originally introduced by Gutenberg and Richter (1956). A similar method has been used also by Koyama and Zheng $(1983,1985)$.

We define $\hat{m}_{b}$ by

$$
\hat{m}_{b}=\log (A g / T)+Q(\Delta)
$$

where $A g$ is the amplitude of the peak ground motion during the $P$-wave train, $T$ is the period of the wave yielding the maximum amplitude, and $Q(\Delta)$ is the empirical Gutenberg-Richter's (1956) amplitude attenuation curve for $P Z$ phase (i.e., $P$ wave recorded by a vertical component seismograph).

The attenuation curve $Q(\Delta)$ determined by Gutenberg and Richter (1956) is for seismic waves recorded by broadband seismographs and may not be directly applicable to the "1-sec" waves recorded by the WWSSN short-period instruments. No allowance is made for possible regional variations of $Q(\Delta)$. If $Q(\Delta)$ is not appropriate to the data set used here, there may be some distance bias in the $\hat{m}_{b}$ measurements. However, we used a large number of records over a wide distance range for each event so that any such bias probably does not affect our results.

We determined the $\hat{m}_{b}$ values of 38 large earthquakes with $M_{W}=5.8$ to 7.7 listed in Table 1 and shown in Figure 1 . The values of $\hat{m}_{b}$ thus determined are listed in Table 2 together with the focal mechanisms and the seismic moments.

For each earthquake, we measured $\hat{m}_{b}$ from 7 to 25 WWSSN records and took the average. The distance range used is $30^{\circ}$ to $100^{\circ}$. The standard deviation of $\hat{m}_{b}$ for each event is approximately 0.25 .

Figure 2 shows the period $T$ of the wave train from which the $\hat{m}_{b}$ values are measured. No significant variation of $T$ with $M_{W}$ is seen. For the events after 1980, the amplitudes and periods were measured on microfiche, and are less accurate than those for events prior to 1980 . 
TABLE 1

List of EARTHQUAKES STUDIED

\begin{tabular}{|c|c|c|c|c|c|c|c|c|c|}
\hline No. & $\begin{array}{c}\text { Month/ } \\
\text { Day }\end{array}$ & Year & $\mathrm{Hr} \cdot \mathrm{Mn}$ & Latitude & Longitude & Region & $\begin{array}{c}\text { Group } \\
\text { No.* }\end{array}$ & PDE $\dagger$ & HVD $\ddagger$ \\
\hline 0 & $10 / 14$ & 1968 & 02.58 & $31.52 \mathrm{~S}$ & $117.00 \mathrm{E}$ & Australia & 2 & 1 & \\
\hline 1 & $7 / 18$ & 1969 & 05.24 & $38.43 \mathrm{~N}$ & $119.47 \mathrm{E}$ & Bohai, China & 3 & $\mathrm{~N}$ & \\
\hline 2 & $1 / 4$ & 1970 & 17.00 & $24.12 \mathrm{~N}$ & $102.49 \mathrm{E}$ & Tonghai, China & 3 & 31 & \\
\hline 3 & $2 / 6$ & 1973 & 10.37 & $31.33 \mathrm{~N}$ & $100.49 \mathrm{E}$ & Luhuo, China & 3 & $\mathrm{~N}$ & \\
\hline 4 & $7 / 14$ & 1973 & 04.51 & $35.16 \mathrm{~N}$ & $086.40 \mathrm{E}$ & Tibet, China & 2 & $\mathrm{~N}$ & \\
\hline 5 & $5 / 10$ & 1974 & 19.25 & $28.19 \mathrm{~N}$ & $103.98 \mathrm{E}$ & Zhaotong, China & 3 & 11 & \\
\hline 6 & $2 / 4$ & 1975 & 11.36 & $40.66 \mathrm{~N}$ & $122.63 \mathrm{E}$ & Haicheng, China & 3 & $\mathrm{~N}$ & \\
\hline 7 & $5 / 29$ & 1976 & 12.23 & $24.51 \mathrm{~N}$ & $098.95 \mathrm{E}$ & Longlin, China & 3 & 8 & \\
\hline 8 & $5 / 29$ & 1976 & 14.00 & $24.54 \mathrm{~N}$ & $098.60 \mathrm{E}$ & Longlin, China & 3 & 10 & \\
\hline 9 & $7 / 27$ & 1976 & 19.42 & $39.56 \mathrm{~N}$ & $117.89 \mathrm{E}$ & Tangshan, China & 3 & 23 & \\
\hline 10 & $7 / 28$ & 1976 & 10.45 & $39.71 \mathrm{~N}$ & $118.37 \mathrm{E}$ & Tangshan, China & 2 & 26 & \\
\hline 11 & $8 / 16$ & 1976 & 14.06 & $32.78 \mathrm{~N}$ & $104.09 \mathrm{E}$ & Songpan, China & 2 & 16 & \\
\hline 12 & $8 / 21$ & 1976 & 21.49 & $32.59 \mathrm{~N}$ & $104.24 \mathrm{E}$ & Songpan, China & 2 & 33 & \\
\hline 13 & $8 / 23$ & 1976 & 03.30 & $32.49 \mathrm{~N}$ & $104.18 \mathrm{E}$ & Songpan, China & 2 & 33 & \\
\hline 14 & $11 / 6$ & 1976 & 18.04 & $27.66 \mathrm{~N}$ & $101.04 \mathrm{E}$ & Yanyuan, China & 2 & 33 & \\
\hline 15 & $11 / 15$ & 1976 & 13.53 & $39.50 \mathrm{~N}$ & $117.73 \mathrm{E}$ & Tangshan, China & 3 & 15 & \\
\hline 16 & $12 / 13$ & 1976 & 06.37 & $27.33 \mathrm{~N}$ & $101.01 \mathrm{E}$ & Yanyuan, China & 3 & 17 & \\
\hline 17 & $9 / 16$ & 1978 & 15.35 & $33.39 \mathrm{~N}$ & $57.43 \mathrm{E}$ & Iran & 2 & 33 & 11 \\
\hline 18 & $1 / \mathbf{1}$ & 1980 & 16.24 & $38.82 \mathrm{~N}$ & $27.78 \mathrm{~W}$ & Azores Island & 3 & 10 & 10 \\
\hline 19 & $2 / 7$ & 1980 & 10.49 & $54.16 \mathrm{~S}$ & $158.89 \mathrm{E}$ & Macquarie Island & 3 & 10 & \\
\hline 20 & $10 / 10$ & 1980 & 12.25 & $36.14 \mathrm{~N}$ & $1.41 \mathrm{E}$ & El Asnam, Algeria & 2 & 10 & 10 \\
\hline 21 & $11 / 8$ & 1980 & 10.27 & $41.12 \mathrm{~N}$ & $124.35 \mathrm{~W}$ & Eureka, California & 3 & 19 & 15 \\
\hline 22 & $1 / 23$ & 1981 & 21.13 & $30.93 \mathrm{~N}$ & $101.10 \mathrm{E}$ & Daofu, China & 3 & 33 & 10 \\
\hline 23 & $2 / 24$ & 1981 & 20.53 & $38.22 \mathrm{~N}$ & $22.93 \mathrm{E}$ & Greece & 2 & 33 & 20 \\
\hline 24 & $4 / 24$ & 1981 & 21.50 & 13.43S & $166.42 \mathrm{E}$ & Vanuatu Island & 1 & 33 & 44 \\
\hline 25 & $4 / 27$ & 1981 & 18.17 & $57.59 \mathrm{~S}$ & $148.08 \mathrm{E}$ & West of Macquarie Island & 3 & 10 & 10 \\
\hline 26 & $7 / 28$ & 1981 & 17.22 & $30.01 \mathrm{~N}$ & $057.80 \mathrm{E}$ & Iran & 2 & 33 & 15 \\
\hline 27 & $9 / 3$ & 1981 & 05.35 & $43.62 \mathrm{~N}$ & $147.03 \mathrm{E}$ & Kuril Island & 1 & 45 & 36 \\
\hline 28 & $11 / 6$ & 1981 & 16.47 & $3.56 \mathrm{~S}$ & $143.79 \mathrm{E}$ & Papua, New Guinea & 3 & 33 & 14 \\
\hline 29 & $11 / 24$ & 1981 & 23.30 & $22.50 \mathrm{~S}$ & $170.64 \mathrm{E}$ & Loyalty Island & 1 & 30 & 23 \\
\hline 30 & $12 / 24$ & 1981 & 05.33 & $29.97 \mathrm{~S}$ & $177.61 \mathrm{~W}$ & Kermadec Island & 1 & 28 & 19 \\
\hline 31 & $8 / 5$ & 1982 & 20.32 & $12.60 \mathrm{~S}$ & $165.93 \mathrm{E}$ & Santa Cruz & 1 & 31 & 24 \\
\hline 32 & $12 / 19$ & 1982 & 17.38 & $124.13 \mathrm{~S}$ & $175.86 \mathrm{~W}$ & South of Tonga & 1 & 33 & 26 \\
\hline 33 & $10 / 28$ & 1983 & 14.06 & $44.06 \mathrm{~N}$ & $113.86 \mathrm{~W}$ & Eastern Idaho & 2 & 10 & 14 \\
\hline 34 & $11 / 16$ & 1983 & 16.13 & $19.43 \mathrm{~N}$ & $155.45 \mathrm{~W}$ & Hawaii & 3 & 12 & 11 \\
\hline 35 & $11 / 30$ & 1983 & 17.46 & $06.86 \mathrm{~S}$ & $072.11 \mathrm{E}$ & Chagos Ridge, Indian Ocean & 2 & 10 & 10 \\
\hline 36 & $2 / 7$ & 1984 & 21.33 & $10.01 \mathrm{~S}$ & $160.47 \mathrm{E}$ & Solomon Island & 1 & 18 & 22 \\
\hline 37 & $3 / 19$ & 1984 & 20.28 & $40.32 \mathrm{~N}$ & $63.35 \mathrm{E}$ & Uzbek, USSR & 2 & 15 & 27 \\
\hline 38 & $3 / 24$ & 1984 & 09.44 & $44.12 \mathrm{~N}$ & $148.19 \mathrm{E}$ & Kuril Island & 1 & 44 & 31 \\
\hline 39 & $8 / 23$ & 1985 & 12.41 & $39.42 \mathrm{~N}$ & $75.27 \mathrm{E}$ & Xinjian, China & 2 & 7 & 15 \\
\hline 40 & $10 / 5$ & 1985 & 15.24 & $62.26 \mathrm{~N}$ & $124.31 \mathrm{~W}$ & Northwest Territories, Canada & 2 & 10 & 10 \\
\hline 41 & $12 / 23$ & 1985 & 05.16 & $62.21 \mathrm{~N}$ & $124.30 \mathrm{~W}$ & Northwest Territories, Canada & 2 & 6 & 15 \\
\hline 42 & $1 / 18$ & 1981 & 18.17 & $38.64 \mathrm{~N}$ & $142.25 \mathrm{E}$ & Honshu, Japan & 1 & 33 & 20 \\
\hline 43 & $1 / 30$ & 1981 & 08.52 & $51.74 \mathrm{~N}$ & $176.27 \mathrm{E}$ & Rat Island & 1 & 33 & 32 \\
\hline 44 & $6 / 7$ & 1982 & 06.52 & $16.61 \mathrm{~N}$ & $98.15 \mathrm{~W}$ & Ometepec, Mexico & 1 & 41 & 11 \\
\hline 45 & $6 / 7$ & 1982 & 10.59 & $16.56 \mathrm{~N}$ & $98.36 \mathrm{~W}$ & Ometepec, Mexico & 1 & 34 & 19 \\
\hline
\end{tabular}

* Group 1 = subduction-zone events; group 2 = nonsubduction-zone dip-slip or oblique-slip events; and group $3=$ strike-slip events.

+ PDE depth.

$\div$ Harvard CMT depth. 
TABLE 2

Source Parameters and Magnitude of the Earthquakes Studied

\begin{tabular}{|c|c|c|c|c|c|c|c|c|c|c|c|}
\hline No. & $\begin{array}{c}\text { Strike } \\
\left({ }^{\circ}\right)\end{array}$ & $\begin{array}{l}\text { Dip } \\
\left({ }^{\circ}\right)\end{array}$ & $\begin{array}{c}\text { Rake } \\
\left({ }^{\circ}\right)\end{array}$ & $\begin{array}{c}\text { Strike } \\
\left({ }^{\circ}\right)\end{array}$ & $\begin{array}{l}\text { Dip } \\
\left({ }^{\circ}\right)\end{array}$ & Rake $\left({ }^{\circ}\right)$ & $\begin{array}{c}M_{0^{*}} \\
\left(10^{26} \mathrm{dyn} / \mathrm{cm}\right)\end{array}$ & Fault Type & $M_{w}$ & $\hat{m}_{b}$ & $\begin{array}{c}T \\
\text { (sec) }\end{array}$ \\
\hline 0 & 338 & 33 & 67 & -175 & 60 & 104 & $0.67(19)$ & 0 & 6.5 & 6.6 & $1.0 \ddagger$ \\
\hline 1 & 24 & 85 & 170 & 115 & 80 & 5 & 2.8 & St & 6.9 & 6.6 & 1.35 \\
\hline 2 & 116 & 86 & 0 & 26 & 90 & 176 & $8.3(15,8)$ & St & 7.2 & 6.7 & 1.45 \\
\hline 3 & -55 & 87 & -179 & 215 & 89 & 177 & $16.0(14,8)$ & St & 7.4 & 6.6 & 1.36 \\
\hline 4 & 177 & 51 & -99 & 11 & 39 & $-79(12)$ & 0.36 & $\mathrm{D}$ & 6.4 & 6.5 & 1.28 \\
\hline 5 & 320 & 80 & 6 & 229 & 84 & 170 & $3.1(8)$ & St & 7.0 & 6.4 & 1.27 \\
\hline 6 & 288 & 78 & 342 & 172 & 72 & 193 & $4.1(3,7)$ & St & 7.0 & 6.7 & 1.56 \\
\hline 7 & 144 & 90 & 180 & 54 & 90 & 0 & $1.1(16)$ & St & 6.7 & 6.5 & 1.47 \\
\hline 8 & 151 & 90 & 180 & 61 & 90 & 0 & $1.5(16)$ & St & 6.8 & 6.5 & 1.52 \\
\hline 9 & 36 & 80 & 17 & -57 & 73 & 170 & $22.0(1,2,13)$ & St & 7.5 & 6.9 & 1.58 \\
\hline 10 & 26 & 61 & 30 & 280 & 64 & 147 & $5.0(1,18)$ & O & 7.1 & 6.7 & 1.49 \\
\hline 11 & 165 & 63 & 40 & 54 & 55 & 146 & $1.3(6)$ & o & 6.7 & 6.9 & 1.45 \\
\hline 12 & 215 & 60 & 90 & 35 & 30 & 90 & $0.40(6)$ & D & 6.4 & 6.7 & 1.61 \\
\hline 13 & 165 & 65 & 40 & 55 & 54 & 149 & $0.84(6)$ & 0 & 6.6 & 6.6 & 1.48 \\
\hline 14 & 42 & 74 & -160 & 306 & 71 & -17 & 0.22 & 0 & 6.2 & 6.5 & 1.38 \\
\hline 15 & 59 & 85 & -170 & 329 & 80 & -5 & 1.5 & St & 6.8 & 6.3 & 1.35 \\
\hline 16 & 289 & 75 & -10 & 22 & 80 & -75 & 0.060 & St & 5.8 & 5.9 & 1.02 \\
\hline 17 & 139 & 45 & 90 & -41 & 45 & 90 & $15.0(10)$ & D & 7.4 & 6.9 & 1.78 \\
\hline 18 & -31 & 86 & 3 & -121 & 87 & 176 & $2.4(9)$ & St & 6.9 & 6.3 & 1.16 \\
\hline 19 & -70 & 84 & 0 & -169 & 90 & 160 & $1.9(9)$ & St & 6.8 & 6.2 & 1.15 \\
\hline 20 & 45 & 54 & 83 & -123 & 37 & 99 & $5.0(4)$ & D & 7.1 & 6.5 & 1.28 \\
\hline 21 & 50 & 90 & 0 & -40 & 90 & 180 & $10.0(9)$ & St & 7.3 & 6.7 & $1.0 \ddagger$ \\
\hline 22 & -40 & 90 & 0 & -130 & 90 & 180 & $1.3(14)$ & St & 6.7 & 6.5 & $1.0 \ddagger$ \\
\hline 23 & 78 & 49 & -106 & 282 & 43 & 288 & $1.3(11)$ & 0 & 6.7 & 6.6 & 1.09 \\
\hline 24 & 165 & 36 & 93 & -187 & 54 & 88 & $2.0(11)$ & $\mathrm{Su}$ & 6.8 & 6.2 & $1.0 \div$ \\
\hline 25 & 349 & 87 & -7 & 79 & 83 & 183 & $1.2(11)$ & $\mathrm{St}$ & 6.7 & 6.1 & $1.0 \ddagger$ \\
\hline 26 & 173 & 28 & 152 & -72 & 77 & 64 & $6.7(11)$ & 0 & 7.2 & 6.9 & 1.59 \\
\hline 27 & 49 & 51 & 128 & 178 & 52 & 52 & $0.90(11)$ & $\mathrm{Su}(H>33 \mathrm{~km})$ & 6.6 & 6.5 & 1.20 \\
\hline 28 & 176 & 87 & -173 & 86 & 83 & 357 & $1.4(11)$ & St & 6.7 & 6.2 & 1.06 \\
\hline 29 & 130 & 70 & 90 & 310 & 29 & 90 & $1.3(11)$ & Su & 6.7 & 6.2 & $1.0 \ddagger$ \\
\hline 30 & 206 & 23 & 111 & 3 & 69 & 81 & $2.1(11)$ & $\mathrm{Su}$ & 6.8 & 6.4 & 1.33 \\
\hline 31 & 341 & 30 & 90 & 161 & 60 & 90 & $3.2(17)$ & $\mathrm{Su}$ & 7.0 & 6.3 & 1.20 \\
\hline 32 & 6 & 68 & 86 & 198 & 22 & 101 & $20.0(17)$ & $\mathrm{Su}$ & 7.5 & 6.4 & 1.28 \\
\hline 33 & 304 & 29 & -103 & 138 & 62 & -83 & $2.8(17)$ & D & 6.9 & 6.6 & 1.40 \\
\hline 34 & 137 & 35 & 8 & 40 & 86 & 125 & $1.2(17)$ & St & 6.7 & 6.7 & 1.19 \\
\hline 35 & 69 & 63 & -113 & 293 & 35 & -52 & $41.0(17)$ & 0 & 7.7 & 7.1 & 1.50 \\
\hline 36 & 296 & 37 & 30 & 182 & 72 & 124 & $25.0(17)$ & $\mathrm{Su}$ & 7.6 & 6.7 & 1.43 \\
\hline 37 & 219 & 28 & 91 & 38 & 62 & 90 & $3.1(5)$ & D & 7.0 & 6.7 & 1.25 \\
\hline 38 & 229 & 17 & 109 & 30 & 74 & 85 & $6.4(17)$ & $\mathrm{Su}(H>33 \mathrm{~km})$ & 7.2 & & \\
\hline 39 & 63 & 80 & 62 & 315 & 29 & 159 & $3.3(17)$ & 0 & 7.0 & & \\
\hline 40 & 340 & 58 & 90 & 160 & 32 & 90 & $0.84(17)$ & D & 6.6 & & \\
\hline 41 & 163 & 45 & 82 & 354 & 45 & 98 & $1.5(17)$ & D & 6.8 & & \\
\hline 42 & 26 & 80 & 99 & -70 & 64 & 95 & $4.0(11)$ & $\mathrm{Su}$ & 7.0 & & \\
\hline 43 & 70 & 70 & 81 & -52 & 28 & 133 & $4.7(11)$ & $\mathrm{Su}$ & 7.1 & & \\
\hline 44 & 130 & 83 & 96 & 268 & 10 & 48 & $2.9(17)$ & Su & 6.9 & & \\
\hline 45 & 121 & 79 & 83 & 286 & 12 & 76 & $2.7(17)$ & $\mathrm{Su}$ & 6.9 & & \\
\hline
\end{tabular}

* The numbers in parentheses correspond to the following references listed below. If more than one reference is cited, the moment values are averaged. For the events without reference, the parameters determined in this study are used. 1 = Butler et al. (1979); 2 = Chen et al. (1979); $3=$ Cipar (1979); $4=$ Deschamps et al. (1982); 5 = Dziewonski et al. (1984); 6 = Jones et al. (1984); 7 = Lin et al. (1979); $8=$ Ma et al. (1982); 9 = Nakanishi et al. (1984); 10= Niazi et al. (1981); 11 = Scott and Kanamori (1985); 12 = Singh and Gupta (1979); $13=$ Zhang et al. (1979); $14=$ Zhou et al. (1983a); $15=$ Zhou et al. (1983b); 16 = Zhou et al. (1984); 17 = Earthquake Data Report; 18 = Tangshan Earthquake (1982); and 19 = Vogfjord and Langston (1985).

$\uparrow \mathrm{St}=$ strike-slip events; $\mathrm{Su}=$ subduction-zone events; $\mathrm{O}=$ oblique events; and $\mathrm{D}=$ dip-slip events. $\doteqdot$ Assumed. 


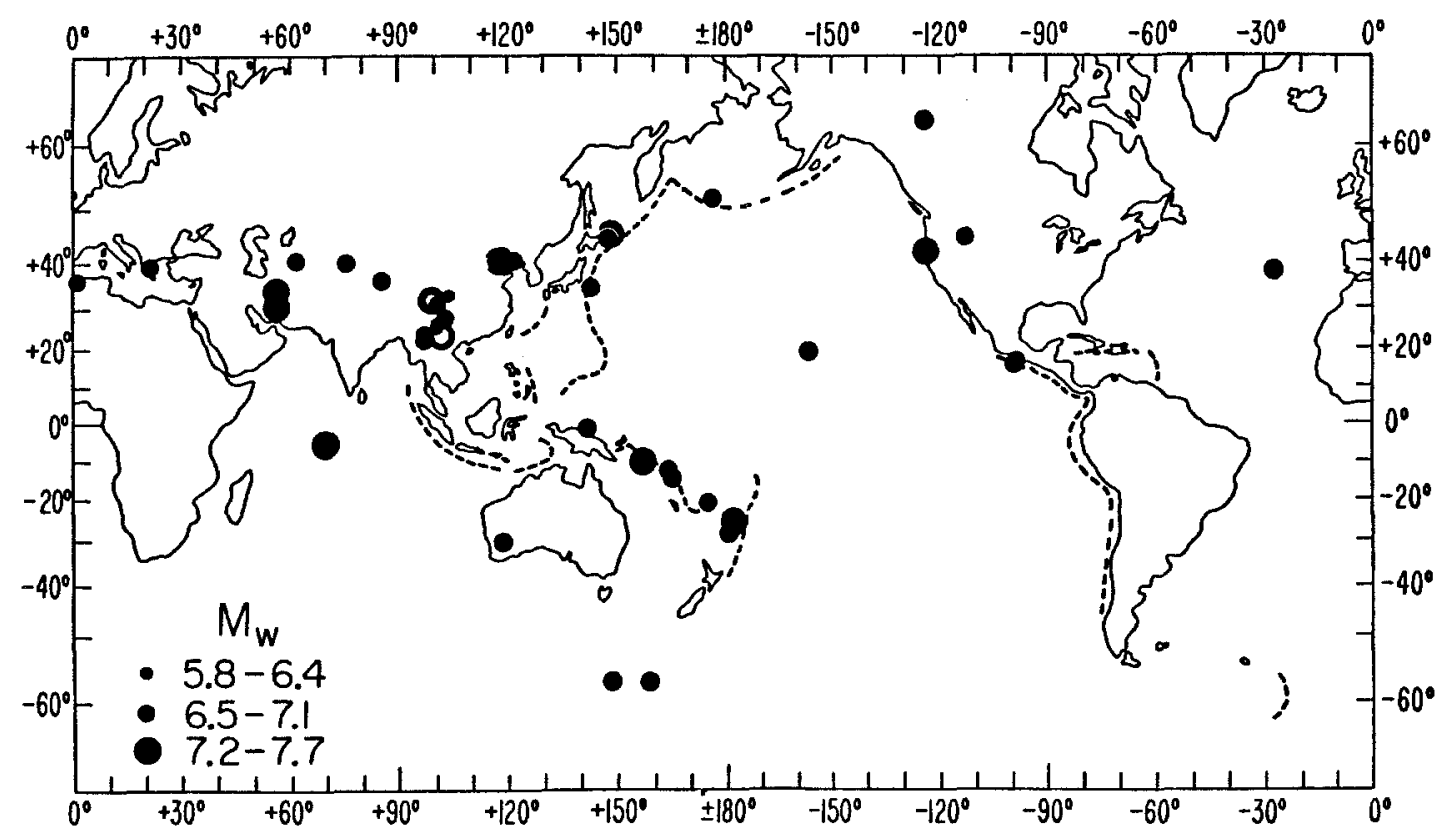

FiG. 1. Locations of the events studied.

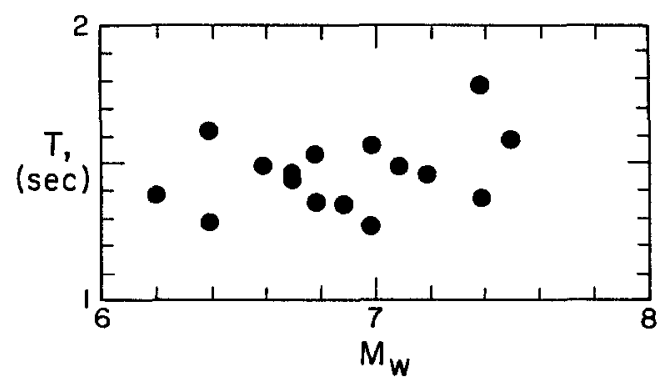

Fig. 2. Period of the wave train for which $\hat{m}_{b}$ values are measured as a function of $M_{W}$. Only events before 1980 are shown.

\section{The Relation Between $\hat{m}_{b}$ and $M_{W}$}

In order to compare the events in different tectonic provinces, we divided our data set into three groups: group 1 (subduction-zone thrust events); group 2 (nonsubduction-zone dip-slip or oblique-slip events); and group 3 (strike-slip events). Although we are primarily interested in intraplate earthquakes, their definition is not straightforward. In contrast, thrust events on subduction-zone interplate boundaries can be distinctly identified. Furthermore, Houston and Kanamori (1986a) have determined $\hat{m}_{b}$ for many subduction-zone events and established a relation between $\hat{m}_{b}$ and $M_{W}$. We therefore form the first group with subductionzone thrust earthquakes and compare other events to it.

The second group consists of dip-slip and oblique-slip events in nonsubductionzone regions. Except event 20 (El Asnam) and event 23 (Greece), we consider all the events in group 2 intraplate events. The third group consists of strike-slip events. Here, we defined strike-slip events by those with a dip angle within $15^{\circ}$ from the vertical and a slip angle within $20^{\circ}$ from the horizontal. We call all other events either dip-slip or oblique-slip. Our reason for grouping the earthquakes in this way is that there is evidence that, for a given surface-wave magnitude, $m_{b}$ for strike-slip 
events is approximately 0.3 units smaller than that of dip-slip events (Eissler and Kanamori, 1986). This difference is probably due to the difference in radiation patterns between the two types of events. For strike-slip events, most teleseismic stations are located close to the radiation node and therefore the recorded amplitudes of $P, p P$, and $s P$ phases are systematically smaller than those for dip-slip or obliqueslip events. Since $m_{b}$ and $\hat{m}_{b}$ are fundamentally-similar, we would expect the same trend for $\hat{m}_{b}$.

In group 3, event 18 (Azores), event 19 (Macquarie Island), event 21 (Eureka, California), event 25 (West of Macquarie Island), and event 28 (Papua, New Guinea) occurred near active plate borders, and event 34 is on the Hawaii Island. All other events in this group occurred in China and are considered intraplate events.

Figure 3a compares the $\hat{m}_{b}$ versus $M_{W}$ relation for group 1 (subduction-zone) with that for group 2 (nonsubduction-zone dip-slip and oblique-slip). This figure includes
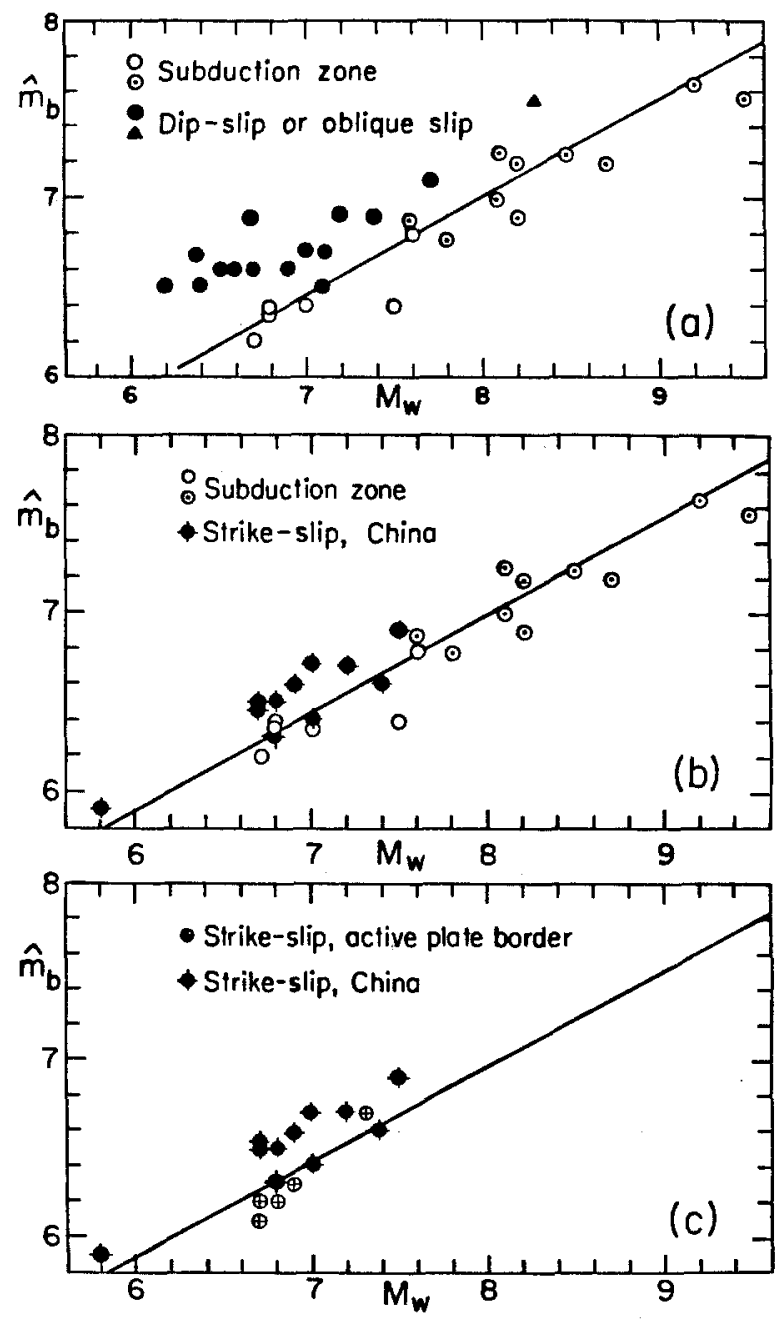

Fig. 3. Comparison of $\hat{m}_{b}$ versus $M_{W}$ relation. Circles with a dot inside and a triangle indicate the data obtained by Houston and Kanamori (1986a). The straight line is a least-squares fit to the subductionzone data. (a) Subduction-zone events and nonsubduction-zone dip-slip or oblique-slip events. (b) Subduction-zone events and the Chinese intraplate strike-slip events. (c) Chinese strike-slip events and strike-slip events near active plate boundaries. 
the data obtained by Houston and Kanamori (1986a). A least-squares fit to the data for subduction-zone events yields a relation $\hat{m}_{b}=0.53 M_{W}+2.66$ which is shown in Figure 3a. This relation is similar to that obtained by Houston and Kanamori (1986a). Although the scatter of the data is considerable, the nonsubduction-zone events (mostly intraplate) have systematically larger (up to 0.6 ) values of $\hat{m}_{b}$ than subduction-zone events with the same $M_{W}$. On the average, the difference is about 0.3. Group 2 includes the 1984 Uzbek, USSR, earthquake, the 1968 Meckering, Australia, earthquake, and the 1978 Tabaz, Iran, earthquake. Houston and Kanamori (1986a) show that $\hat{m}_{b}$ is approximately proportional to the logarithm of the spectral amplitude at the period where the $\hat{m}_{b}$ is measured [see equation (6) and Figure 9 of Houston and Kanamori, 1986a]. Thus, the above result suggests that the source spectral amplitudes of intraplate earthquakes at $1.4 \mathrm{sec}$ are about 2 to 4 times larger than those of subduction-zone events with the same $M_{W}$.

Figure $3 \mathrm{~b}$ compares the $\hat{m}_{b}$ versus $M_{W}$ relation for the Chinese intraplate strikeslip events (a subset of group 3) with that for group 1 (subduction-zone events). The $\hat{m}_{b}$ values for the Chinese strike-slip events are on the average 0.1 to 0.2 units larger than those for subduction-zone events for an $M_{W}$ range from 6.5 to 7.5 . Considering that $m_{b}$ for strike-slip events is systematically lower by 0.3 than $m_{b}$ for dip-slip events (Eissler and Kanamori, 1986), the result shown in Figure 3b indicates that the source spectral amplitudes of the Chinese intraplate strike-slip events are 0.4 to $0.5 \hat{m}_{b}$ units larger than those for subduction-zone events.

In order to examine whether the Chinese intraplate strike-slip events are systematically different from strike-slip events along active plate boundaries, we compare the $\hat{m}_{b}$ versus $M_{S}$ relations for these two groups of events in Figure 3c. The latter group includes the 1980 Azores Island earthquake, the 1980 and 1981 Macquarie Island earthquakes, the 1980 Eureka, California, earthquake, and the 1981 Papua, New Guinea, earthquake. The $\hat{m}_{b}$ values for the Chinese intraplate earthquakes are about 0.2 units larger than those for plate-boundary events with the same $M_{W}$. However, since the available data base is relatively small, this conclusion should be considered tentative.

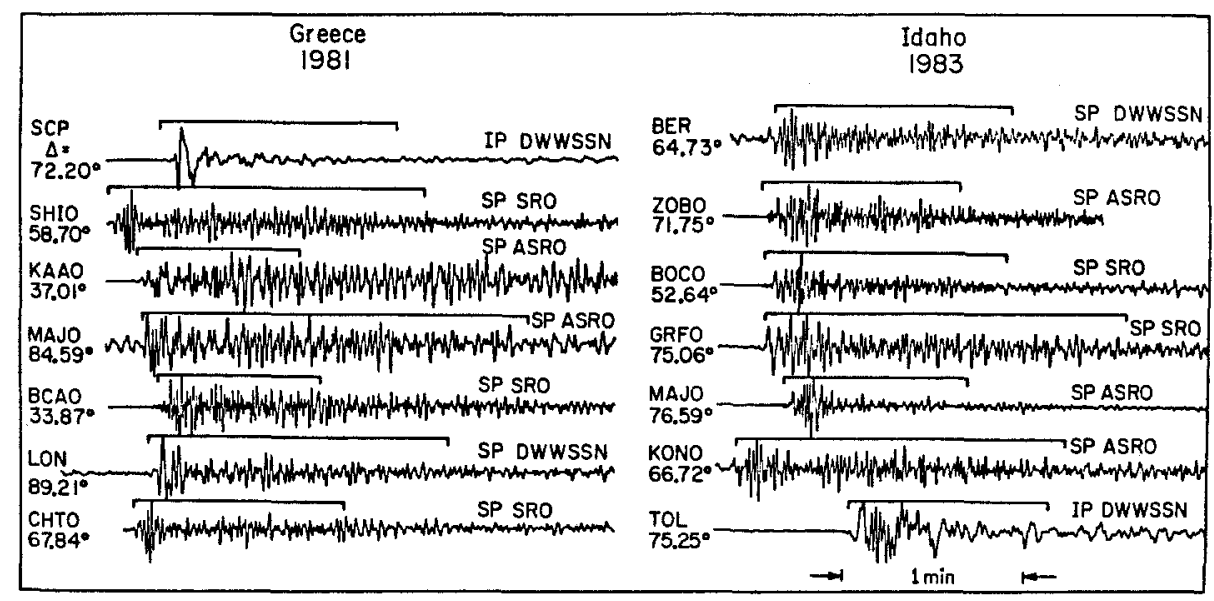

FIG. 4. Digital intermediate- and short-period seismograms of the 1981 Greece earthquake and the 1983 Idaho earthquake. The line segment above each record indicates the window length used for the Fourier transform. 


\section{SOURCE SPECTRUM}

Although $\hat{m}_{b}$ is a simple and useful parameter, the period range where $\hat{m}_{b}$ is determined is narrow, around $1.4 \mathrm{sec}$ (Figure 2). It is desirable to determine the source spectrum directly. Hartzell and Heaton (1985) determined the source spectrum of many large earthquakes using seismograms recorded by the Benioff longperiod seismograph at Pasadena.

The short- and intermediate-period digital seismograms which recently became available from the GDSN are well suited to this purpose. Several recent studies used this data set to investigate the source spectrum (Boatwright and Choy; 1986a, b; Houston and Kanamori, 1986a). Houston and Kanamori (1986a, b) analyzed the digital seismograms for the seven largest earthquakes between 1980 and 1983 to determine the source spectra.

We used the procedure described by Houston and Kanamori (1986a) to determine the source spectrum using the GDSN seismograms. We window and then Fouriertransform the $P$-wave train. The window length is about 1 to $2 \mathrm{~min}$. Normally, the window includes the trace from the beginning of the $P$-wave train to the point where the amplitude is reduced to 25 per cent of the maximum amplitude. The $P P$ phase is not included. Figure 4 shows examples of the seismograms and illustrates the windows.

The moment rate spectrum $\hat{M}(\omega)$ is given by

$$
\hat{\dot{M}}(\omega)=\frac{4 \pi \rho \alpha^{3} R_{E}}{g(\Delta) R_{\theta \phi} C}\left[e^{\omega t^{*} / 2} \hat{u}(\omega) / \hat{I}(\omega)\right]
$$

where $\rho$ and $\alpha$ are the density and $P$-wave velocity at the source, $R_{E}$ is the radius of the earth, $g(\Delta)$ represents geometrical spreading, $R_{\theta \phi}$ is the effective radiation pattern factor of the $P$-wave train that includes the $P, p P$, and $s P$ phases, $C$ is the free-surface receiver effect, $t^{*}$ is the attenuation parameter (e.g., Der and Lees, 1985 ), and $\hat{I}(\omega)$ is the instrument response. For the calculation of $R_{\theta \phi}$, we used the method employed by Houston and Kanamori (1986) which is similar to that used by Boatwright and Choy (1986a). The contribution of $s P$ phase is slightly different between the two methods. Houston and Kanamori (1986) used a standard dislocation model to compute the ratio of $S$ to $P$ radiation patterns, while Boatwright and Choy (1986a) used an empirically determined ratio. For the purpose of the present study, the difference is insignificant. If the source is localized at a certain depth, distinct arrivals of $P, p P$, and $s P$ phases cause an interference pattern in the spectrum (Boatwright and Choy, 1986b). The moment rate spectrum defined by (2) is also called the source spectrum.

One difficulty exists concerning the effective radiation pattern for strike-slip earthquakes. The effective radiation pattern factor $R_{\theta \phi}$ is a function of azimuth and take-off angle. Figure 5 shows $R_{\theta \phi}$ as a function of azimuth (the take-off angle is fixed at $30^{\circ}$ ) for four representative source mechanisms. For strike-slip events, all of the stations are close to the radiation node so that the average amplitude is expected to be much smaller than that for other mechanisms. If the curves shown in Figure 5 are used, the average (over-azimuth) amplitude of strike-slip events should be at least 4 times smaller than that of other mechanisms. However, the difference in $m_{b}$ is only about 0.2 to 0.3 (Eissler and Kanamori, 1986), corresponding to a ratio of 1.6 to 2 in amplitude. This discrepancy is probably due to scattering of short-period $P$ waves near the source. The $P$-wave train of teleseismic seismograms 


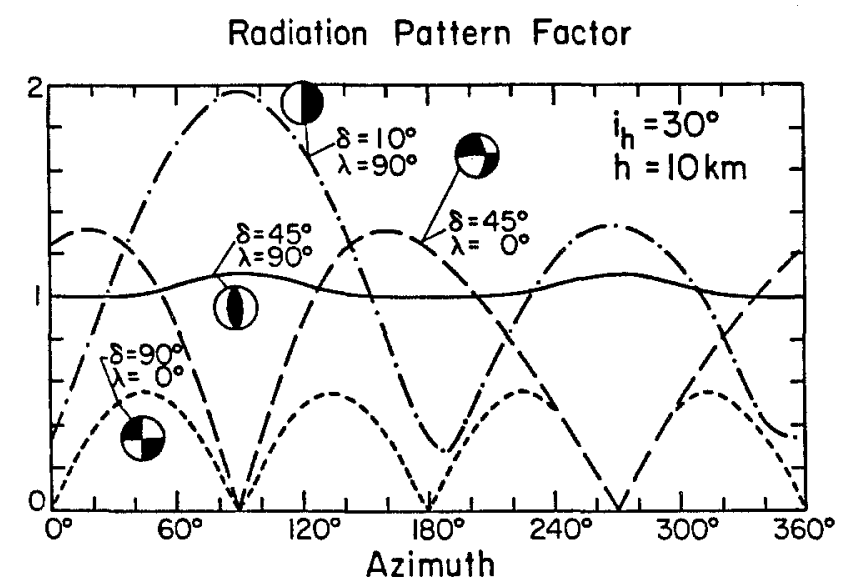

FIG. 5. The azimuthal variation of the radiation pattern factor for four representative focal mechanisms $\left(\delta=\operatorname{dip}, \lambda=\right.$ rake). The take-off angle is fixed at $30^{\circ}$, and the depth is fixed at $10 \mathrm{~km}$.

contains significant scattered energy, radiating from the source around the take-off angle of the $P$-wave ray. Hence, in computing the radiation pattern factor, it is more appropriate to take the average over the focal sphere than to use the value for a single ray. We computed the average over the entire focal sphere, $\bar{R}_{\theta \phi}$, for the four mechanisms shown in Figure 5 in a manner similar to that of Boore and Boatwright (1984). The averages are 1.1 ( $45^{\circ}$ dip-slip mechanism), $0.81\left(10^{\circ}\right.$ dip-slip mechanism), 0.67 ( $45^{\circ}$ strike-slip mechanism), and 0.46 (vertical strike-slip mechanism). We also computed the average over the range of take-off angle from $0^{\circ}$ to $50^{\circ}$. The averages are $1.1,0.98,0.73$, and 0.34 for the above four mechanisms. The ratio of $\bar{R}_{\theta \phi}$ for nonstrike-slip events to that of strike-slip events ranges from 1.4 to 2.5 (for the average over entire focal sphere) and 1.3 to 2.0 (for a take-off angle range, $10^{\circ}$ to $50^{\circ}$ ), which agrees with the value inferred from the $m_{b}$ data of Eissler and Kanamori (1986). As Boore and Boatwright (1984) showed, if a narrow range of take-off angle $\left(17^{\circ}\right.$ to $\left.25^{\circ}\right)$ is used, the ratio is much larger, 4.7 to 5.5 .

In view of this difficulty, we analyzed the data in two ways. In the first case, we use $R_{\theta \phi}$ computed for the actual source-station geometry. In the second case, we used the average $\bar{R}_{\theta \phi}$ for all of the stations. Except for the events of group 3 (strikeslip), the difference in the estimate of the spectral amplitude between the two cases is insignificant. However, for group 3, the difference is approximately a factor of 2 .

In this paper, we present the spectral data for groups 1 and 2 obtained by using the actual radiation pattern factors. For group 3, we present the result obtained by using the average factor.

Since all of the events studied here are large events which involve a substantial part of the crust, we use $\rho=2.9 \mathrm{gm} / \mathrm{cm}^{3}$ and $\alpha=6.5 \mathrm{~km} / \mathrm{sec}$ (if $\rho=2.67 \mathrm{gm} / \mathrm{cm}^{3}$, and $\alpha=6.1 \mathrm{~km} / \mathrm{sec}$ are used, $\hat{M}(\omega)$ should be reduced by 27 per cent). The geometrical spreading factor $g(\Delta)$, the radiation pattern factor $R_{\theta \phi}$, and the freesurface receiver effect are included in the same way as in Houston and Kanamori (1986a). We assumed that $t^{*}$ does not depend on the distance and frequency, and used a constant value of $0.7 \mathrm{sec}$. The uncertainties in $t^{*}$ introduce errors in $\dot{M}(\omega)$, especially at short periods.

Many recent studies have demonstrated significant regional variations of $t^{*}$ (e.g., Der and Lees, 1985). In the present study, we used $t^{*}=0.7 \mathrm{sec}$. However, a variation of $t^{*}$ from 0.5 to $1.0 \mathrm{sec}$ is commonly reported for individual paths. At $1 \mathrm{sec}$, the 
TABLE 3

Stations Used FOR THE ANALYsis

\begin{tabular}{|c|c|c|c|c|}
\hline Event No. & Station & $\Delta\left(^{\circ}\right)$ & Azimuth $\left({ }^{\circ}\right)$ & $R_{\beta \phi}$ \\
\hline \multirow[t]{6}{*}{18} & $\mathrm{BCAO}$ & 54.18 & 117.08 & 0.44 \\
\hline & $\mathrm{BOCO}$ & 53.99 & 243.00 & 0.13 \\
\hline & ZOBO & 66.57 & 222.73 & 0.16 \\
\hline & KAAO & 73.79 & 58.39 & 0.08 \\
\hline & ANTO & 46.06 & 68.52 & 0.14 \\
\hline & KONO & 31.45 & 36.18 & 0.52 \\
\hline \multirow[t]{4}{*}{19} & СHTO & 88.85 & 304.14 & 0.28 \\
\hline & NWAO & 36.21 & 288.79 & 0.29 \\
\hline & CTAO & 35.37 & 339.73 & 0.71 \\
\hline & MAJO & 92.11 & 343.41 & 0.28 \\
\hline \multirow[t]{5}{*}{20} & BOCO & 75.58 & 265.24 & 1.22 \\
\hline & СHTO & 85.01 & 70.35 & 1.11 \\
\hline & $\mathrm{KAAO}$ & 54.14 & 70.289 & 0.87 \\
\hline & ZOBO & 83.80 & 244.97 & 1.21 \\
\hline & JAS & 88.75 & 317.92 & 1.28 \\
\hline \multirow[t]{3}{*}{21} & MAJO & 72.05 & 303.06 & 0.18 \\
\hline & ZOBO & 77.18 & 125.04 & 0.14 \\
\hline & GRFO & 81.86 & 27.36 & 0.25 \\
\hline \multirow[t]{5}{*}{22} & ANTO & 55.22 & 299.47 & 0.17 \\
\hline & BCAO & 81.46 & 270.19 & 0.25 \\
\hline & NWAO & 65.34 & 165.15 & 0.35 \\
\hline & MAJO & 31.13 & 69.64 & 0.54 \\
\hline & GUMO & 43.65 & 103.35 & 0.43 \\
\hline \multirow[t]{7}{*}{23} & CHTO & 67.84 & 82.96 & 1.26 \\
\hline & $\mathrm{BCAO}$ & 33.87 & 187.90 & 0.95 \\
\hline & SHIO & 58.70 & 80.58 & 1.29 \\
\hline & KAAO & 37.01 & 81.15 & 1.36 \\
\hline & $\mathrm{SCP}^{*}$ & 73.20 & 308.94 & 0.77 \\
\hline & LON & 89.21 & 336.69 & 0.81 \\
\hline & MAJO & 84.59 & 46.89 & 1.03 \\
\hline \multirow[t]{6}{*}{24} & TATO & 58.11 & 310.94 & 1.14 \\
\hline & NWAO & 48.72 & 237.88 & 1.45 \\
\hline & СHTO & 73.76 & 294.26 & 1.22 \\
\hline & LON & 87.60 & 40.87 & 1.07 \\
\hline & GUMO & 56.36 & 140.53 & 0.93 \\
\hline & MAJO & 56.37 & 332.80 & 1.03 \\
\hline \multirow[t]{4}{*}{25} & MAJO & 94.14 & 352.02 & 0.09 \\
\hline & CHTO & 86.32 & 314.03 & 0.21 \\
\hline & CTAO & 37.46 & 356.17 & 0.24 \\
\hline & NWAO & 32.38 & 306.32 & 0.51 \\
\hline \multirow[t]{3}{*}{26} & KONO & 43.63 & 326.76 & 0.93 \\
\hline & GRFO & 39.93 & 312.76 & 0.68 \\
\hline & TATO & 56.10 & 78.61 & 0.50 \\
\hline \multirow[t]{6}{*}{27} & CHTO & 47.16 & 254.02 & 0.56 \\
\hline & KAAO & 59.16 & 289.97 & 0.79 \\
\hline & KONO & 71.30 & 338.79 & 1.10 \\
\hline & KWAO & 80.87 & 205.12 & 1.00 \\
\hline & $\mathrm{LON}^{*}$ & 60.72 & 51.93 & 1.23 \\
\hline & SCP* & 86.74 & 32.37 & 1.18 \\
\hline \multirow[t]{3}{*}{28} & NWAO & 38.33 & 217.32 & 0.69 \\
\hline & ТАТО & 35.68 & 328.81 & 0.52 \\
\hline & SNZO & 46.71 & 147.88 & 0.44 \\
\hline
\end{tabular}


TABLE 3-Continued

\begin{tabular}{|c|c|c|c|c|}
\hline Event No. & Station & $\Delta\left({ }^{\circ}\right)$ & Azimuth $\left({ }^{\circ}\right)$ & $R_{9 \phi}$ \\
\hline \multirow[t]{3}{*}{29} & NWAO & 48.80 & 24.50 & 1.84 \\
\hline & MAJO & 66.20 & 331.80 & 0.96 \\
\hline & JAS & 83.30 & 47.50 & 1.46 \\
\hline \multirow[t]{4}{*}{30} & LON & 91.40 & 34.77 & 0.90 \\
\hline & $A L Q$ & 93.00 & 51.27 & 0.96 \\
\hline & NWAO & 54.89 & 248.55 & 1.67 \\
\hline & JAS & 86.00 & 41.85 & 0.91 \\
\hline \multirow[t]{5}{*}{31} & GUMO & 33.44 & 320.60 & 0.85 \\
\hline & NWAO & 48.71 & 237.24 & 0.61 \\
\hline & TATO & 57.28 & 310.90 & 0.78 \\
\hline & LON & 87.36 & 41.02 & 1.29 \\
\hline & JAS & 85.19 & 49.63 & 1.34 \\
\hline \multirow[t]{5}{*}{32} & CTAO & 35.34 & 268.95 & 1.94 \\
\hline & LON & 85.78 & 33.96 & 0.86 \\
\hline & COL* & 91.41 & 11.58 & 0.86 \\
\hline & JAS & 80.70 & 41.29 & 0.85 \\
\hline & ANMO & 88.13 & 50.37 & 0.93 \\
\hline \multirow[t]{7}{*}{33} & BOCO & 52.64 & 126.48 & 1.33 \\
\hline & GRFO & 75.06 & 33.29 & 1.12 \\
\hline & KONO & 66.72 & 27.41 & 1.10 \\
\hline & MAJO & 76.59 & 308.15 & 0.94 \\
\hline & ZOBO & 73.10 & 133.96 & 1.19 \\
\hline & BER & 64.73 & 28.59 & 1.12 \\
\hline & TOL* & 75.25 & 48.36 & 1.26 \\
\hline \multirow[t]{9}{*}{34} & ZOBO & 92.87 & 106.04 & 0.77 \\
\hline & SNZO & 66.46 & 204.18 & 0.48 \\
\hline & BOCO & 80.41 & 88.41 & 0.65 \\
\hline & GUMO & 57.28 & 274.01 & 1.26 \\
\hline & ANMO & 45.80 & 59.82 & 0.24 \\
\hline & COL & 45.73 & 4.55 & 0.86 \\
\hline & GDH & 76.15 & 21.01 & 0.47 \\
\hline & SCP & 68.33 & 52.86 & 0.14 \\
\hline & LON & 38.71 & 38.71 & 0.25 \\
\hline \multirow[t]{7}{*}{35} & KONO & 82.54 & 332.95 & 1.33 \\
\hline & GRFO & 71.12 & 324.38 & 1.43 \\
\hline & GUMO & 75.02 & 74.05 & 0.84 \\
\hline & NWAO & 49.17 & 128.03 & 0.76 \\
\hline & $\mathrm{BCAO}$ & 54.66 & 280.34 & 1.29 \\
\hline & SLR & 45.78 & 240.64 & 0.87 \\
\hline & $\mathrm{KEV}$ & 82.40 & 345.58 & 1.29 \\
\hline \multirow[t]{4}{*}{36} & CHTO & 67.06 & 295.24 & 1.01 \\
\hline & LON* & 88.90 & 42.26 & 0.80 \\
\hline & JAS & 87.69 & 51.03 & 0.91 \\
\hline & $\mathrm{COL}^{*}$ & 84.01 & 19.69 & 0.59 \\
\hline \multirow[t]{6}{*}{37} & SCP & 91.96 & 331.58 & 1.30 \\
\hline & COL* & 72.47 & 13.29 & 1.51 \\
\hline & LON $^{*}$ & 93.33 & 3.44 & 1.15 \\
\hline & $\mathrm{KEV}^{*}$ & 35.14 & 339.09 & 1.65 \\
\hline & $\mathrm{GDH}^{*}$ & 61.40 & 332.72 & 1.65 \\
\hline & TOL* & 50.29 & 292.86 & 1.68 \\
\hline \multirow[t]{2}{*}{38} & CTAO & 63.81 & 182.30 & 0.58 \\
\hline & GRFO & 79.49 & 333.42 & 1.31 \\
\hline
\end{tabular}


TABLE 3-Continued

\begin{tabular}{|c|c|c|c|c|}
\hline Event No. & Station & $\Delta\left(^{\circ}\right)$ & Azimuth ( $\left.{ }^{\circ}\right)$ & $R_{\theta \phi}$ \\
\hline & ANMO & 76.01 & 54.67 & 0.70 \\
\hline & LON* & 59.68 & 52.71 & 0.61 \\
\hline & GDH & 65.90 & 8.38 & 0.85 \\
\hline & TOL & 92.89 & 339.22 & 1.10 \\
\hline & $\mathrm{COL}^{*}$ & 40.34 & 36.19 & 0.50 \\
\hline \multirow[t]{10}{*}{39} & $\mathrm{LON}$ & 92.86 & 11.63 & 0.91 \\
\hline & $\mathrm{COL}^{*}$ & 70.69 & 17.94 & 1.07 \\
\hline & $\mathrm{GDH}$ & 65.29 & 342.24 & 1.51 \\
\hline & KEV & 39.43 & 335.89 & 1.74 \\
\hline & SLR & 78.26 & 222.45 & 0.34 \\
\hline & KONO & 45.02 & 319.19 & 1.63 \\
\hline & MAJO & 45.80 & 72.33 & 0.38 \\
\hline & GRFO & 45.49 & 305.09 & 1.49 \\
\hline & ANTO & 32.49 & 284.67 & 1.22 \\
\hline & CTAO & 88.78 & 117.12 & 0.95 \\
\hline \multirow[t]{7}{*}{40} & SHIO & 87.82 & 327.82 & 1.13 \\
\hline & ANTO & 76.57 & 17.89 & 0.97 \\
\hline & TOL & 67.49 & 45.93 & 0.82 \\
\hline & GRFO & 62.94 & 30.67 & 0.81 \\
\hline & KONO & 53.39 & 27.08 & 0.72 \\
\hline & $\mathrm{SCP}$ & 34.92 & 105.94 & 0.57 \\
\hline & $\mathrm{KEV}$ & 46.73 & 132.25 & 0.72 \\
\hline \multirow[t]{8}{*}{41} & TOL & 67.50 & 46.50 & 0.82 \\
\hline & $\mathrm{SCP}^{*}$ & 34.90 & 105.94 & 0.56 \\
\hline & $\mathrm{KEV}^{*}$ & 46.80 & 13.26 & 0.72 \\
\hline & ANTO & 76.60 & 17.93 & 0.96 \\
\hline & GRFO & 63.00 & 30.72 & 0.80 \\
\hline & MAJO & 61.70 & 294.90 & 1.29 \\
\hline & KONO & 53.40 & 27.11 & 0.72 \\
\hline & ZOBO & 89.80 & 127.07 & 1.01 \\
\hline \multirow[t]{7}{*}{42} & KONO & 74.40 & 337.42 & 1.22 \\
\hline & LON & 66.40 & 48.43 & 0.47 \\
\hline & ANTO & 79.00 & 312.52 & 1.44 \\
\hline & CHTO & 42.70 & 255.08 & 1.50 \\
\hline & KAAO & 57.80 & 290.61 & 1.78 \\
\hline & GRFO & 82.20 & 330.61 & 1.23 \\
\hline & CTAO & 58.50 & 176.14 & 0.73 \\
\hline \multirow[t]{11}{*}{43} & KAAO & 73.10 & 304.48 & 1.40 \\
\hline & GRFO & 78.20 & 350.10 & 1.49 \\
\hline & CHTO & 67.70 & 272.18 & 1.02 \\
\hline & ANTO & 83.40 & 332.49 & 1.44 \\
\hline & ANMO & 56.00 & 75.09 & 0.61 \\
\hline & LON & 39.70 & 71.90 & 0.56 \\
\hline & TATO & 49.10 & 258.59 & 0.84 \\
\hline & SCP & 67.70 & 52.13 & 0.85 \\
\hline & KONO & 68.40 & 352.74 & 1.61 \\
\hline & JAS & 45.60 & 81.70 & 0.54 \\
\hline & CTAO & 76.20 & 208.90 & 0.75 \\
\hline \multirow[t]{4}{*}{44} & LON & 35.90 & 331.91 & 0.81 \\
\hline & KONO & 84.50 & 29.08 & 1.38 \\
\hline & SCP & 29.80 & 31.98 & 1.94 \\
\hline & KEV & 85.80 & 16.58 & 1.27 \\
\hline
\end{tabular}


TABLE $3-$ Continued

\begin{tabular}{ccccc}
\hline Event No. & Station & $\Delta\left(^{\circ}\right)$ & Azimuth $\left(^{\circ}\right)$ & $R_{\text {s申 }}$ \\
\hline \multirow{2}{*}{45} & LON & 35.80 & 332.40 & 1.15 \\
& SCP & 30.00 & 32.16 & 2.02 \\
& ZOBO & 44.20 & 136.08 & 0.34 \\
& KEV & 85.90 & 16.40 & 1.37 \\
\hline
\end{tabular}

* For stations with an asterisk, intermediate-band records are used. For others, short-period records are used.
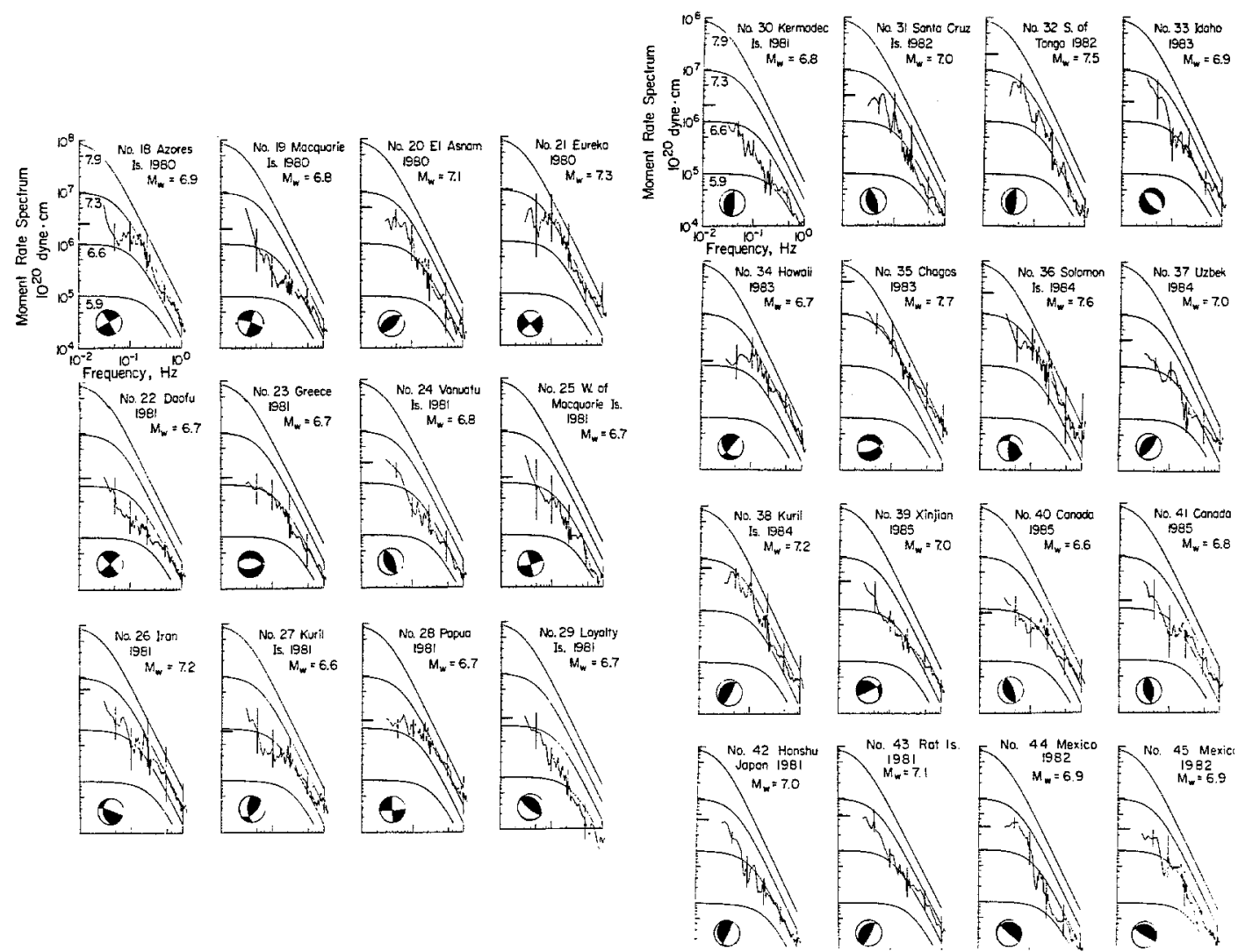

FIG. 6. The average moment rate spectra for the 28 earthquakes studied. Theoretical spectra for an $\omega$-square model are shown as a reference. The vertical bars are the standard deviations. The short horizontal bars at the left indicate the seismic moments determined from long-period waves. The stations used for each event are listed in Table 3.

attenuation factor $a=\exp \left(-\pi t^{*} / T\right)$ is $0.21,0.11$, and 0.043 for $t^{*}=0.5,0.7$, and 1.0 sec, respectively. Therefore, the estimate of the spectral amplitude at $1 \mathrm{sec}$ is in error by a factor of about 2 if $t^{*}$ is either 0.5 or $1.0 \mathrm{sec}$ instead of the assumed value of $0.7 \mathrm{sec}$. In our analysis, spectra are averaged for different paths so that the path effect is considerably reduced. However, the source effect cannot be averaged out. At $2 \mathrm{sec}$, however, the attenuation factor is $0.46,0.33$, and 0.21 , for $t^{*}=0.5,0.7$, and 1.0 respectively. The estimated spectral amplitudes at periods longer than $2 \mathrm{sec}$ are therefore relatively insensitive to the variation of $t^{*}$. In order to improve the 
accuracy of our spectral measurements, more accurate measurements of $t^{*}$ for specific paths are necessary.

For each earthquake, 3 to 10 corrected spectra are averaged to obtain the average moment rate spectrum. Table 3 lists the stations used for the analysis. The results are shown in Figure 6, with the standard deviations given at selected periods. Theoretical spectra for an $\omega$-square model $\hat{M}(\omega)=M_{0} \omega_{c}{ }^{2} /\left(\omega_{c}{ }^{2}+\omega^{2}\right)$, where $\omega_{c} / 2 \pi$ $=0.49 \beta\left(\Delta \sigma / M_{0}\right)^{1 / 3}$ with $\Delta \sigma=3 \times 10^{7}$ dyne $/ \mathrm{cm}^{2}$ (30 bars) and $\beta=3.75 \times 10^{5} \mathrm{~cm} /$ $\sec (3.75 \mathrm{~km} / \mathrm{sec})$ are shown in the figures only as a reference. No attempt is made here to fit the data by these theoretical curves.

\section{The Relation Between $\hat{\dot{M}}(\omega)$ and $M_{W}$}

In order to compare the spectra between different events, we read the spectral amplitudes at 1, 2, 5, and $10 \mathrm{sec}$ from Figure 6 for each earthquake, and plotted them as a function of $M_{W}$ in Figure 7. Figure 7 compares the results for group 1 (subduction-zone events) and group 2 (nonsubduction-zone dip-slip and obliqueslip events). The data obtained earlier by Houston and Kanamori (1986a, b) are included in these figures. The straight lines are the least-squares fit to the subduction-zone events. The values of $a$ and $b$ for the straight line, $\log \hat{\dot{M}}(\omega)=a+b M_{W}$, are $(a=18.72, b=0.78),(20.39,0.62),(19.58,0.81)$, and $(20.39,0.77)$ for $1,2,5$, and $10 \mathrm{sec}$, respectively. The value of $b$ is larger than 0.5 , the expected value for the $\omega$-square model, indicating that the high-frequency spectral decay is more gradual than the $\omega$-square model. Figure 7 shows that, at periods of 1 and $2 \mathrm{sec}$, the average spectral amplitudes of intraplate events are 2 to 4 times larger than those of subduction-zone events with the same $M_{W}$. However, this difference decreases as the period increases toward $10 \mathrm{sec}$, as shown by Figure 7.

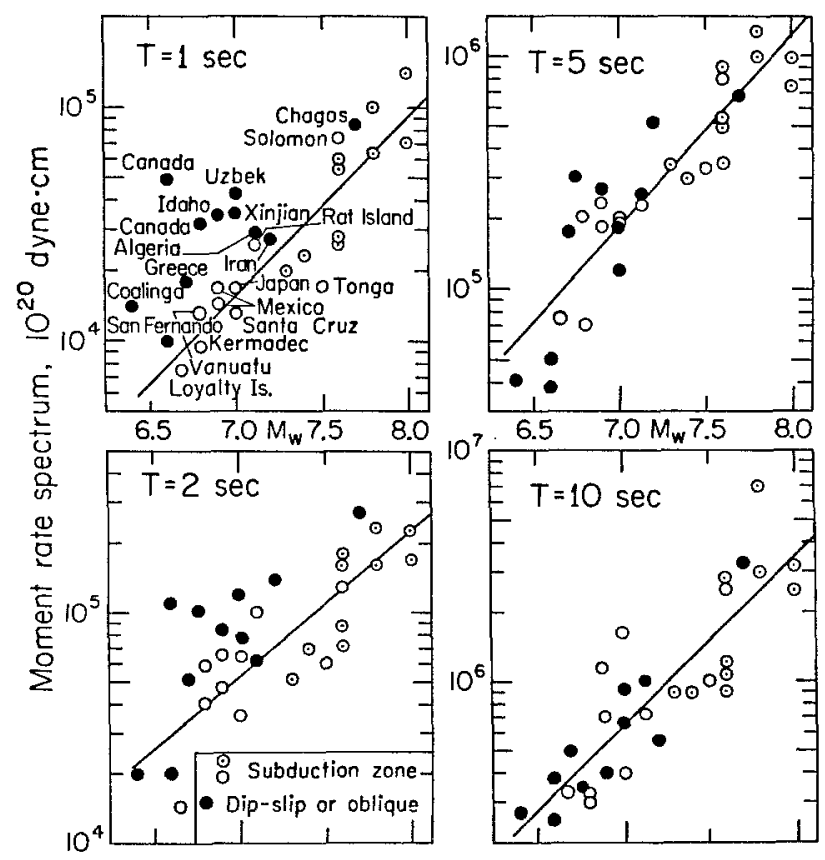

FIG. 7. The relation between moment rate spectrum and $M_{W}$ at $1,2,5$, and $10 \mathrm{sec}$. Open circles indicate events in subduction zones. Open circles with a dot inside indicate subduction-zone events studied by Houston and Kanamori (1986a). The data for the San Fernando and the Coalinga earthquakes are also taken from Houston and Kanamori (1986a). The solid circles indicate nonsubduction-zone dipslip or oblique-slip events. The straight lines are least-squares fit to the subduction-zone events. 


\section{CONCLUSIONS}

Our results, obtained from both $\hat{m}_{b}$ data and spectral data, suggest that, at a 1to 2 -sec period, intraplate events have larger spectral amplitudes (2 to 4 times) than subduction-zone events. The difference decreases at a 10 -sec period. Comparison of $\hat{m}_{b}$ values for strike-slip events in intraplate regions with those near-plate boundaries suggest that, for a given $M_{W}, \hat{m}_{b}$ values for intraplate events are 0.2 unit larger than those for plate-boundary events. However, since the presently available data are rather sparse, this conclusion should be considered tentative.

Kanamori and Allen (1986) examined the relation between the fault length and the earthquake magnitude, and conclude that, for a given magnitude, earthquakes with long repeat times have shorter fault lengths than those with short repeat times. This result suggests a difference in the average stress drop between intraplate and interplate earthquakes. For a given seismic moment, a factor of 5 difference in the stress drop would predict a factor of 3 difference in the short-period spectral amplitude, if an $\omega$-square source model is used. The result obtained in the present study is generally consistent with the inference made by Kanamori and Allen (1986).

\section{ACKNOWLEDGMENTS}

We thank Heidi Houston, Jack Boatwright, and Dave Boore for useful comments on the manuscript. This research has been supported by the U.S. Geological Survey Grants No. 14-08-0001-G1171 and 1408-0001-G1170. Contribution No. 4359, Division of Geological and Planetary Sciences.

\section{REFERENCES}

Archambeau, C. B. (1978). Estimation of nonhydrostatic stress in the earth by seismic methods: lithospheric sress levels along Pacific and Nazca plate subduction zones, in Proc. Conf. II, Methodology for Identifying Seismic Gaps and Soon to Break Gaps, U.S. Geol. Surv., Open-File Rept. 78.93.

Boatwright, J. and G. L. Choy (1986a). Teleseismic estimates of the energy radiated by shallow earthquakes, J. Geophys. Res. 91, 2095-2112.

Boatwright, J. and G. L. Choy (1986b). Acceleration spectra for subduction zone earthquakes (abstract), $\operatorname{EOS~67,~} 310$.

Boore, D. M. (1983). Stochastic simulation of high-frequency ground motion based on seismological models of the radiated spectra, Bull. Seism. Soc. Am. 73, 1865-1894.

Boore, D. M. and J. Boatwright (1984). Average body-wave radiation coefficients, Bull. Seism. Soc. Am. 74, 1615-1621.

Butler, R., G. S. Stewart, and H. Kanamori (1979). The July 27, Tangshan, China earthquake-A complex sequence of intraplate events, Bull. Seism. Soc. Am. 69, 207-220.

Chen, Y., L.-R. Huang, B.-H. Lin, M.-L. Lui, and X. Wang (1979). A dislocation model of the Tangshan earthquake of 1976 from the inversion of geodetic data, Acta Geophysica Sinica 22, 201-217 (in Chinese, English abstract).

Cipar, J. (1979). Source processes of the Haicheng, China, earthquake from observation of $P$ and $S$ waves, Bull. Seism. Soc. Am. 69, 1903-1916.

Der, Z. A. and A. C. Lees (1985). Methodologies for estimating $t^{*}(f)$ from short-period body waves and regional variations of $t^{*}(f)$ in the United States, Geophys. J. R. Astr. Soc. 82, 125-140.

Deschamps, A., Y. Gaudemer, and A. Cisternas (1982). The El Asnam, Algeria, earthquake of 10 October 1980: multiple-source mechanism determined from long-period records, Bull. Seism. Soc. Am. 72, 1111-1128.

Dziewonski, A. M., J. E. Franzen, and J. H. Woodhouse (1984). Centroid-moment tensor solution for January-March, 1984, Phys. Earth Planet. Interiors 34, 209-219.

Eissler, H. K. and H. Kanamori (1986). Depth estimates of large earthquakes on the island of Hawaii since 1940, J. Geophys. Res. 91, 2063-2076.

Gutenberg, B. and C. F. Richter (1956). Magnitude and energy of earthquakes, Ann. Geofis. 9, 1-15.

Hartzell, S. H. and T. H. Heaton (1985). Teleseismic time functions for large, shallow subduction zone earthquakes, Bull. Seism. Soc. Am. 75, 965-1004. 
Houston, H. and H. Kanamori (1986a). Source spectra of great earthquakes: Teleseismic contrains on rupture process and strong motion, Bull. Seism. Soc. Am. 76, 19-42.

Houston, H. and H. Kanamori (1986b). Source characteristics of the 1985 Michoacan, Mexico earthquake at periods of 1 to 30 seconds, Geophys. Res. Letters 13, 597-600.

Jones, L. M., W. Han, E. Hauksson, A. Jin, Y. Zhang, and Z. Luo (1984). Focal mechanisms and aftershock locations of the Songpan earthquakes of August 1976 in Sichuan, China, J. Geophys. Res. 89, 7697-7707.

Kanamori, H. and C. R. Allen (1986). Earthquake repeat time and average stress drop, Maurice Ewing Series, Volume 6, Earthquake Source Mechanics, American Geophysical Union, Washington, D.C.

Koyama, J. and S. Zheng (1985). Excitation of short-period body waves by recent great earthquakes, Phys. Earth Planet. Interiors 37, 108-123.

Koyama, J. and S. Zheng (1983). Excitation of short-period body waves by recent great earthquakes, Zisin, J. Seism. Soc. Japan 36, 237-245 (in Japanese, English abstract).

Lin, B.-H., Y.-T. Chen, F.-S. Wei, and Z.-Y. Li (1979). A study of asymmetrically bilateral rupture process with application to the Haicheng earthquake, Acta Seismologica Sinica 1, 133-149.

Liu, H.-L. and H. Kanamori (1980). Determination of source parameters of mid-plate earthquakes from the waveforms of body waves, Bull. Seism. Soc. Am. 70, 1989-2004.

Ma, Z., Fu C., Y. Zhang, C. Wang, Q. Zhang, and D. Liu (1982). Nine Large Earthquakes of China from 1966 to 1976, Seismological Press, Beijing, China, 8-9.

Nakanishi, I. and H. Kanamori (1984). Source mechanisms of twenty-six large, shallow earthquakes ( $m$ $\geqq 6.5)$ during 1980 from $P$-wave first motion and long-period Rayleigh wave data, Bull. Seism. Soc. Am. 74, 805-818.

Niazi, M. and H. Kanamori (1981). Source parameters of 1978 Tabas and 1979 Qainat, Iran, earthquake from long-period surface waves, Bull. Seism. Soc. Am. 71, 1201-1213.

Nuttli, O. W. (1983). Average seismic source-parameter relations for mid-plate earthquakes, Bull. Seism. Soc. Am. 73, 519-535.

Scott, D. R. and H. Kanamori (1985). On the consistency of moment tensor source mechanism with first-motion data, Phys. Earth Planet. Interiors 37, 97-107.

Singh, D. D. and H. K. Gupta (1979). Source mechanism and surface wave attenuation studies for Tibet earthquake of July 14, 1973, Bull. Seism. Soc. Am. 69, 737-750.

State Seismological Bureau (1980). The Tangshan Earthquake of 1976, S. Mei, Editor, Seismological Press, Beijing, China, p. 43.

Vogfjord, K. S. and C. A. Langston (1985). Source parameters of the Ms 6.8 Meckering, Australia earthquake of October 14, 1968: "a chip off of the old block", EOS 66, 963.

Zhang, Z., G.-Z. Li, J.-C. Gu, Y.-M. Jin, M.-Y. Yang, and W.-Q. Liu (1980). The Fracture processes of the Tangshan earthquake and its mechanical analysis, Acta Seismologica Sinica 2, 111-129.

Zhou, H.-L., H.-L. Liu, and H. Kanamori (1983a). Source processes of large earthquakes along the Xianshuihe fault in southwestern China, Bull. Seism. Soc. Am. 73, 537-551.

Zhou, H.-L., C. R. Allen, and H. Kanamori (1983b). Rupture complexity of the 1970 Tonghai and 1973 Luhuo earthquakes, China, from $P$-wave inversion, and relationship to surface faulting, Bull. Seism. Soc. Am. 73, 1585-1597.

Zhou, H.-L., H. Kanamori, and C. R. Allen (1984). Analysis of complex earthquakes and source processes of Longling, Acta Geophysica Sinica 27, 523-536.

\author{
SEISMOLOGICAL LABORATORY \\ California Institute of Technology \\ Pasadena, California 91125
}

Manuscript received 19 August 1986 